\title{
Katetrizační ablace v léčbě komorových tachykardii po infarktu myokardu - kurativní výkon nebo součást hybridní terapie?
}

\author{
Jan Bytešník
}

Klinika kardiologie, Institut klinické a experimentální medicíny, Praha, Česká republika

Indikace a výběr léčby u komorových tachykardií (KT) zohledňují kromě symptomů především prognostickou závažnost dané arytmie. Ta je determinována typem posuzované tachyarytmie, základním srdečním postižením (včetně nálezu na věnčitých tepnách a funkce levé komory) a celkovým stavem organismu. Příznivým prognostickým ukazatelem je poměrně dobrá kontraktilní funkce nezvětšené levé komory (s ejekční frakcí $\geq 0,4$ ) a nepřítomnost klinicky významnějšího strukturálního srdečního postižení. $\mathrm{V}$ medicínské praxi jsou však často neostré hranice mezi benigními a potenciálně maligními komorovými arytmiemi; tato skutečnost má být respektována při volbě léčebných postupů a při hodnocení jejich účinků. Rozhodujícím hlediskem přitom je účinné potlačení rizika náhlé srdeční smrti (NSS).

V tomto čísle Cor et Vasa je publikována kasuistika J. Palčíka a spolupracovníků „Léčba mnohočetných poinfarktových setrvalých monomorfních komorových tachykardií katetrovou ablací bez implantace ICD - kdy je toto řešení možné?“.(1) Tato problematika zasluhuje komentář, nebot podle současných doporučení Evropské kardiologické společnosti i České kardiologické společnosti by pacient s uvedenou tachyarytmií mohl být přednostně indikován $\mathrm{k}$ léčbě implantabilním kardioverterem-defibrilátorem (ICD). ${ }^{(2-4)}$

Řada studií ukázala, že pacienti po proběhlé epizodě setrvalé KT jsou ohroženi recidivami komorových tachyarytmií. Dominantní postavení v léčbě závažných KT v rámci tzv. sekundární prevence NSS zaujímá ICD. Opodstatnění této léčby se opírá především o výsledky tří prospektivních randomizovaných studií - AVID, CIDS a CASH. ${ }^{(5)}$ Jejich závěry jsou konzistentní a při jednoletém a delším sledování ukazují relativní snížení celkové mortality o 20-37 \% ve prospěch léčby ICD ve srovnání s amiodaronem či jiným antiarytmikem nebo betablokátorem. Metaanalýza uvedených tři sekundárně-preventivních studií, v nichž jasně převažovali pacienti s koronární nemocí, konstatovala relativní snížení mortality náhlou smrtí o $57 \%$. $^{(5)} \mathrm{V}$ rámci obecně uznávaných indikací

Adresa: MUDr. Jan Bytešník, CSc., Klinika kardiologie, Institut klinické a experimentální medicíny, Vídeňská 1958/9, 14021 Praha 4, Česká republika, e-mail: jaby@medicon.cz léčby ICD jsou v indikační třídě I nemocní s dokumentovanou setrvalou KT či s fibrilací komor (FK), a to jak při strukturálním srdečním postižení, tak $\mathrm{u}$ arytmických syndromů bez prokazatelného organického onemocnění srdce. ${ }^{(2,3,6,7)}$

Další léčebnou možností, která může být $\mathrm{v}$ některých př́padech dokonce kurativním výkonem, je cílená chirurgická nebo katetrizační ablace arytmogenního substrátu. ${ }^{(2,4)}$ Typickým arytmogenním substrátem u pacientů po infarktu myokardu jsou okrajové oblasti jizvy a jejího okolí. Pokud jde o stabilní reentry okruh, je možno jej úspěšně ovlivnit ablační léčbou. Nadějnější v tomto směru je chirurgická ablace, která radikálněji odstraňuje oblasti srdeční tkáně s abnormálními signály a $\mathrm{s}$ porušeným šířením vzruchu, které mohou podmiňovat vznik a udržení reentry mechanismu. Katetrizační ablace byly do nedávné doby podstatně méně spolehlivou léčbou, zejména $\mathrm{u}$ pacientů $\mathrm{s}$ rozsáhlejším arytmogenním substrátem, který mohl být podkladem rưzných reentry okruhů, případně i jiných arytmogenních mechanismů. Nové techniky s využitím elektroanatomického mapování a účinnější katetrizační ablace (například s použitím katetrů k docílení hlubších lézí) zvyšují úspěšnost ablačních metod. ${ }^{(8-11)} U$ některých forem KT, které mají kritickou část reentry okruhu lokalizovanou subepikardiálně, je možno $\mathrm{k}$ provedení katetrizační ablace použít epikardiální přístup. I při použití nových, progresivních technologií se však akutní úspěšnost této léčby pohybuje obvykle mezi 70-80 \% a při 2-3letém sledování jsou uváděny recidivy KT zhruba u 35-50 \% léčených pacientů. ${ }^{(8,10-12)}$ Proto je dosud u pacientů s KT po infarktu myokardu katetrizační ablace považována za doplňující terapii, která zatím nemůže nahradit léčbu $\operatorname{ICD}{ }^{(8,10,12)}$

Problémem u ablační léčby je, že dosud neexistují dostatečné údaje o tom, zda je možno ponechat alespoň některé pacienty s významným strukturálním postižením srdce po úspěšné katetrizační ablaci bez zajištění ICD. Není jasné, jak dlouhý interval bez recidivy KT po ablaci má dostatečně silnou prediktivní hodnotu o nízkém riziku recidivy $\mathrm{KT}$. $\mathrm{V}$ tomto směru probíhají nyní prospektivní studie a jasnější odpověd' budeme mít v průběhu dalších let. Spolehlivou odpověd' nelze čekat od kasuistik, nota bene, pokud mají poměrně krátkou dobu sledování, jako v př́ípadě 
kasuistiky J. Palčíka a spol. Je dobře známo, že proces negativní remodelace myokardu u koronární nemoci po předchozím infarktu myokardu pokračuje i v delším odstupu od koronární příhody a že riziko výskytu komorových tachykardií stoupá s časem od prodělaného infarktu myokardu. ${ }^{(13-15)}$ Navíc je třeba zdůraznit limitace testů elektrické komorové stability. ${ }^{(16)}$ Negativní výsledek kontrolního elektrofyziologického testování po ablační léčbě není zárukou, že se nevyskytne spontánní KT v následujícím období. Senzitivita a specificita programované stimulace komor pro detekci trvajícího zvýšeného rizika recidiv KT není tak vysoká, abychom mohli považovat pacienta $\mathrm{s}$ poinfarktovou dysfunkcí levé komory a s provedenou katetrizační ablací či modifikací arytmogenního substrátu za dostatečně ochráněného proti NSS. Navíc dosud není dostatečně zřejmé, jaký podíl na střednědobé a dlouhodobé stabilitě klinického stavu mají další léčebné postupy včetně revaskularizace myokardu a současné optimální farmakoterapie. I přes použití kombinace různých diagnostických testů $\mathrm{k}$ zhodnocení rizika budoucího výskytu $\mathrm{KT}$, není $\mathrm{v}$ současnosti stratifikace rizika NSS dostatečně spolehlivá. ${ }^{(17)}$ Je velmi pravděpodobné, že výpovědní hodnota jednotlivých testů se mění $\mathrm{v}$ čase - tj. během vývoje strukturálního srdečního postižení. Proto je na místě rezervovanost v hodnocení akutních či krátkodobých výsledků ablační léčby KT u pacientů se strukturálním onemocněním srdce. Současná praxe je taková, že $\mathrm{v}$ rámci sekundární prevence NSS, tedy u pacientů se strukturálním onemocnění srdce a zachycenou setrvalou KT, je přednostně indikována implantace ICD. ${ }^{(2-4,6,7)}$ Ablační léčba představuje užitečnou doplňující léčbu v rámci tzv. hybridní terapie, přičemž takto docílená modifikace či izolace arytmogenního substrátu může výrazně snížit frekvenci epizod KT nebo usnadní jejich potlačení elektroterapií ICD či farmakoterapií. Katetrizační ablaci jako kurativní postup - bez potřeby zajištění pacienta ICD - lze zatím akceptovat $\mathrm{v}$ léčbě idiopatických KT nebo u pacientů s málo pokročilou formou organického srdečního postižení, s dobrou funkcí levé komory, u nichž zatím KT nebyla hemodynamicky závažná a nebyla spojena s výraznějšími symptomy.

\section{LITERATURA}

1. Palčík J, Fiala M, Chovančík J, Branny M. Léčba mnohočetných poinfarktových setrvalých monomorfních komorových tachykardií katetrovou ablací bez implantace ICD - kdy je toto řešení možné? Cor Vasa 2006; 48(9):321-4.

2. Priori SG, Aliot E, Blomstrom-Lundqvist C, et al. Update of the guidelines on sudden cardiac death of the European Society of Cardiology. Eur Heart J 2003;24:13-5.

3. Táborský M, Kautzner J, Bytešník J, et al. Zásady pro implantace kardiostimulátorů, implantabilních kardioverterů-defibrilátorů a srdeční resynchronizační léčbu (2005). Cor Vasa 2005;47:59-68.

4. Bytešník J, Táborský M, Kautzner J, et al. Doporučené postupy pro diagnostiku a léčbu komorových arytmií. Cor Vasa 2005;47:41-57.

5. Connolly SJ, Hallstrom AP, Cappato R, et al. Meta-analysis of the implantable cardioverter-defibrillator secondary prevention trials. Eur Heart J 2000;21:2071-8.

6. Hauer RNW, Aliot $\mathrm{E}$, Block $\mathrm{M}$, et al. Indications for implantable cardioverter-defibrillator (ICD) therapy. Study group on guidelines on ICD of the Working Group on Arrhythmias and Cardiac Pacing of the European Society of Cardiology. Europace 2001;3:169-76.

7. Gregoratos G, Abrams J, Epstein AE, et al. ACC/AHA/ NASPE 2002 Guideline update for implantation of cardiac pacemakers and antiarrhythmia device: summary article. J Cardiovasc Electrophysiol 2002;13:1183-99.

8. Stevenson WG, Friedman PL, Kocovic D, et al. Radiofrequency catheter ablation of ventricular tachycardia after myocardial infarction. Circulation 1998;98:308-14.

9. Kautzner J, Čihák R, Peichl P, Vančura V, Bytešník J. Catheter ablation of ventricular tachycardia following myocardial infarction using a 3-D electroanatomical mapping. PACE 2003;26:342-7.

10. Calkins H, Epstein A, Packer D, et al. Catheter ablation of ventricular tachycardia in patients with structural heart disease using cooled radiofrequency energy: results of a prospective multicenter study. Cooled RF Multi Center Investigators Group. J Am Coll Cardiol 2000; 35:1905-14.

11. Kottkamp H, Wetzel U, Schirdewahn P, et al. Catheter ablation of ventricular tachycardia in remote myocardial infarction: Substrate description guiding placement of individual linear lesions targeting noninducibility. J Cardiovasc Electrophysiol 2003;14:675-81.

12. Segal OR, Chow AW, Markides V, et al. Long-term results after ablation of infarct-related ventricular tachycardia. Heart Rhythm 2005;2:483-4.

13. Wilber DJ, Zareba W, Hall WJ, et al. Time dependence of mortality risk and defibrillator benefit after myocardial infarction. Circulation 2004;109:1082-4.

14. Sutton MStJ, Lee D, Rouleau JL, et al. Left ventricular remodeling and ventricular arrhythmias after myocardial infarction. Circulation 2003;107:2577-82.

15. Jugdutt BI. Ventricular remodeling after infarction and the extracellular collagen matrix. When is enough enough? Circulation 2003;108:1395-403.

16. Buxton A, Hafley G, Lehmann M, et al. Prediction of sustained ventricular tachycardia inducible by programmed stimulation in patiens with coronary artery disease: utility of clinical variables. Circulation 1999; 99: 1843-50.

17. Hohnloser SH, Gersch BJ. Changing late prognosis of acute myocardial infarction. Impact on management of ventricular arrhythmias in the era of reperfusion and the implantable cardioverter-defibrillator. Circulation 2003; 107:941-6. 